\title{
The myths of modern primitivism
}

\section{ABSTRACT}

1.
RE/Search Publications' Modern Primitives (Vale and Juno 1989) changed countless lives, bringing what had been a localized and niche set of body modification practices, aesthetics and philosophies out of San Francisco to a global audience, dominating scholarly and popular discourse around body modification subculture for more than a decade afterwards. The voice of Fakir Musafar dominates the book.

This article argues that modern primitives as Musafar defines them never really existed (and never could have existed) in the terms he suggests, and goes on to address an important sub-strand within Modern Primitives almost entirely ignored by critics and commentators, who have read the book as generally representative of the body modification culture as a whole. With specific reference to contributors such as infamous tattoo artist Don Ed Hardy who do not frame their practice in 'primitive' terms, the article concludes with a study of an alternative account presented by Vale and Juno's book: body modification as artistic practice.

Christian Klesse defines 'Modern Primitives' as 'a subcultural movement in the intersection of the tattoo, piercing and sado-masochism scenes'. This 'movement', he explains, 'originated in the 1970s in California, USA, growing in numbers and significance in the following decades' (Klesse 2000). Virginia Eubanks' definition is broader: 'Modern Primitives', she says, 'are loosely defined as those who participate in contemporary rituals that include extensive body piercing, constriction (binding), scarification, "tribal"

\section{KEYWORDS}

tattoos

modern primitives

body art

body modification Don Ed Hardy

Fakir Musafar 
1. In Modern Primitives, Musafar says he coined the term in 1967. In other writings elsewhere, he says 1978 (Musafar 1996: 325). tattooing, and branding' (Eubanks 1996). Michael Atkinson describes how the neo-primitives are considered 'the most influential of the new groups of tattoo artists and enthusiasts' (Atkinson 2003: 45). A report by The Institute of Cultural Research floridly describes how

Today's 'modern primitives' use tattoos, piercings and other forms of skin design to perform almost exactly the same functions as that of our ancestors: they use them to forge 'tribal' affiliations - and within that circle they have come to represent a collective common language and set of aesthetic values.

(Institute for Cultural Research 2000)

To take such critics at their word would be to assume that there exists or existed a vast community of people coalescing around an organizing philosophy, selfidentifying as individuals or groups under the labels 'modern primitive', 'neoprimitive' and 'neo-tribalist'. The movement has dominated the sociological, anthropological and cultural studies literature on contemporary body modification practices in the West and is so pervasive in academic discourse that even works that devote themselves to body modification practices, philosophies and frameworks beyond the 'primitive' paradigm (Atkinson 2003; Fenske 2007; MacCormack 2006; Pitts 2003; Sanders 2008; Sullivan 2001) feel compelled to at least make reference to the notion of modern primitivism, if only to comprehensively reject its tenets.

The term 'modern primitive' was coined in the mid-1970s by a body modification practitioner known as Fakir Musafar (Musafar 1996, 2002, 2003; Vale and Juno 1989). ${ }^{1}$ According to Musafar, a 'modern primitive' is 'a nontribal person who responds to primal urges and does something with the body' (Musafar in Vale and Juno 1989: 15), with 'primal urges' understood to mean some aculturally innate drive to mark, decorate or otherwise alter one's own body. Inspired from childhood by photographs in the National Geographic Magazine and by anthropology textbooks to ape and appropriate so-called 'primitive' body modification practices including tattooing, piercing, scarification, branding and flesh-hook suspension, Musafar and a small clique of associates from southern California developed a philosophy and way of life based on what they called 'body play', which they saw as directly oppositional to and as spiritually, ethically and even psychologically preferable to the 'civilized' culture of America and the West.

Musafar's modern primitivism combines participation in a bewilderingly disparate set of tribal body practices with an ill-defined and woolly conception of spirituality. From the piercings of the Masai to the ecstatic dances of Indian sadhus, from Maori tattoos to Native American flesh-hanging rituals and from the penile implants of Japanese Yakuza gangs to the stretched necks of the Padung women of Thailand, any form of body modification or bodily orientated ritual with an appropriately 'tribal' lineage is deemed appropriate for appropriation and redeployment in the pursuit of self-discovery. The concept came to prominence following the publication in 1989 of Modern Primitives - An Investigation of Contemporary Adornment and Ritual by V. Vale and Andrea Juno (Vale and Juno 1989, see Figure 1) and the book, as Nikki Sullivan explains, 'has now achieved something of a cult status' (Sullivan 2001: 36). It is the touchstone text for studies of contemporary Western body modification practices. Every critical engagement with the 'Modern Primitives' or 'neo-tribal' movement is grounded in discussions of it; it is treated by
1.

2.

3.

4.

5.

6.

7.

8.

9.

10.

11.

12.

13.

14.

15.

16.

17.

18.

19.

20.

21.

22.

23.

24.

25.

26.

27.

28.

29.

30.

31.

32.

33.

34.

35.

36.

37.

38.

39.

40.

41.

42.

43.

44.

45.

46.

47.

48.

49.

50.

51.

52. 


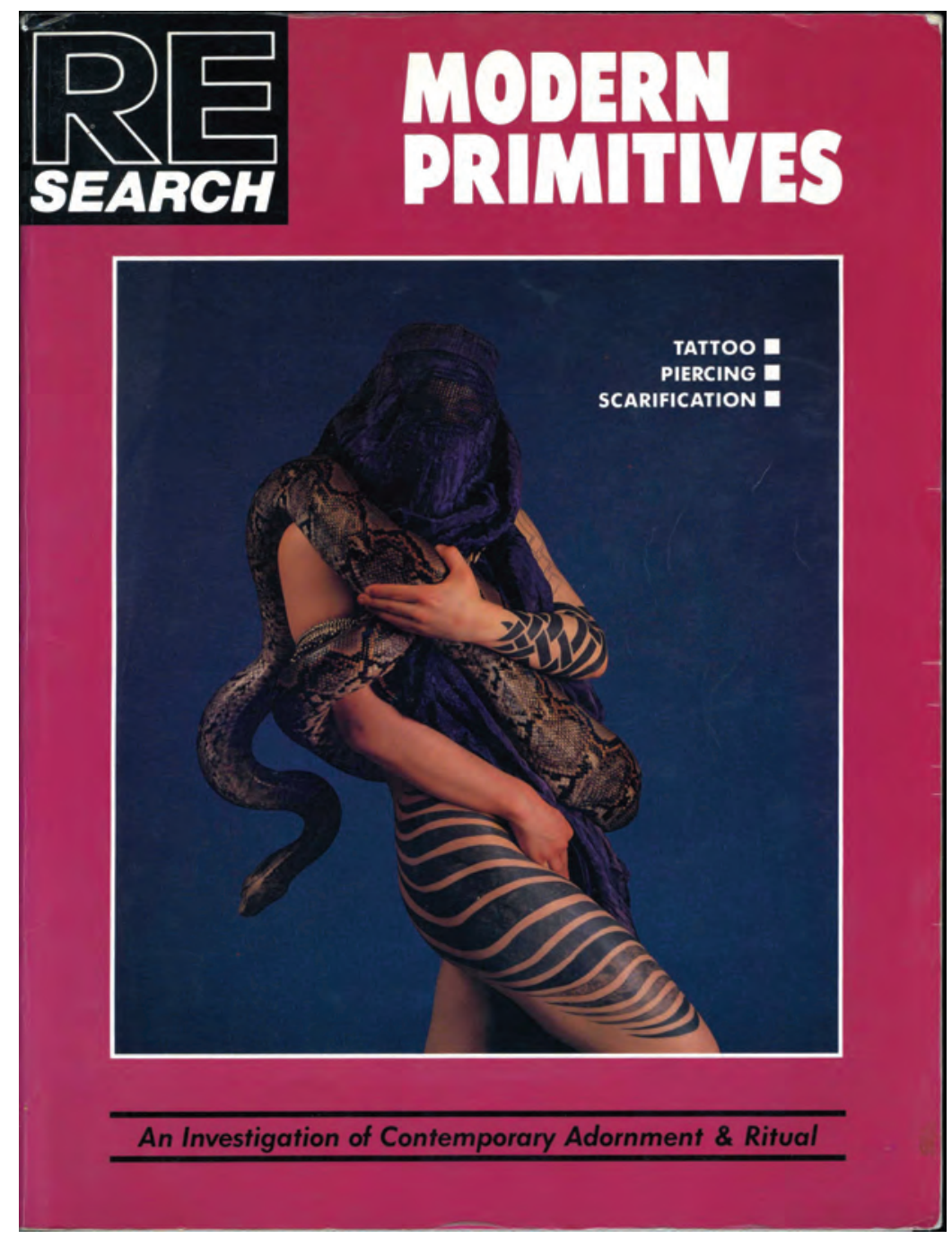

Figure 1: Modern Primitives (San Fransisco : RE/Search, 1989). Cover.

commentators as a manifesto or the Bible of a defined movement (e.g. in Rosenblatt 1997: 298) and the ideas expressed within it are often taken for the purposes of criticism as representative of body modification more generally (Turner 2000).

The problem is not only that nothing that could truly be called a movement of self-identified 'Modern Primitives' ever existed either before the book was published or afterwards, but also that the book itself has been repeatedly misrepresented, with analysis of large swathes of the interviews within it almost entirely absent from the literature. Almost every piece of writing I have cited thus far is harshly and, I would argue, justifiably critical of Musafar's ideas and ideology. They are idealistic, idealizing and even potentially offensive. They rely on some extraordinarily naïve and muddled conceptions of traditional non-Western bodily practices. They pick and choose from practices from an 
2. A previous version of Musafar's article published elsewhere renders this as 'atavists' (Favazza 1996: 327. Quotes in original).

3. See also Siorat (2005) enormous range of time-periods and geographical locations and attempt to mash them together into a coherent set of beliefs and aims. In short, they do not hold up to the sustained scrutiny to which they have been subjected. Nevertheless, I want to argue that although this criticism is for the most part entirely correct, it is also almost universally quixotic.

\section{‘MODERN PRIMITIVES’ IN MODERN PRIMITIVES}

There are two distinct mistakes that saturate the discussions of Modern Primitives: assuming everyone in the book subscribes to a philosophy informed by primitivism, and that this philosophy is reflective of how a larger movement of individuals relate to their bodies and the modification practices they undergo. The first error is born out of a shallow reading of the book as a whole: Musafar's ideas do not make up the whole of Modern Primitives; they occupy only 36 of its 200-plus pages, and Musafar cannot legitimately be said to be ideologically representative of anything other than his own ideas. When writers such as Eubanks and Klesse write about 'Modern Primitives', they are writing only about Fakir Musafar and 'a handful of other activists' from his immediate social circle (Musafar 2003: 28). ${ }^{2}$ Rosenblatt (1997) argues that 'looking at the book, it seems as though the whole history of Western speculation about other cultures has been tossed into a blender with more than a little New Age mysticism and some contemporary sexual radicalism thrown in besides', but whilst this certainly applies to much of Musafar's philosophy, this criticism cannot fairly be levelled at the book as a whole.

Klesse's article is a particularly glaring example of this tendency to treat Musafar's ideas as presented in Modern Primitives as not only representative of a coherent philosophy espoused by all those Vale and Juno interviewed, but also as a synecdoche of all body modification practice in the West then and since. 'Vale and Juno's influential book', he explains, 'contains a sample of interviews with people (mainly tattoo artists) who locate themselves within Modern Primitivism' (Klesse 2000: 17). This is simply not true: of the 24 interviews in the book, only two - those with Musafar and his close friend and acquaintance Jim Ward - explicitly describe their own practices in these specific terms. ${ }^{3}$ Several are inspired by certain aesthetic features of blackwork tattooing, which is quite different from a full-scale, metaphysically inspired appropriation of 'primitivism' as a defined set of ethical behaviours. Others, like Genesis P-Orridge, seem to define their relationship with tattooing and body piercing in terms conceptually quite oppositional to those espoused by Musafar: 'I don't think [these practices] are primitive', he states (Genesis P-Orridge in Vale and Juno 1989: 178. Emphasis in original). And for others, the term 'primitive' does not seem apposite at all: how can the term sensibly apply to Sheree Rose or Raelyn Gallina, for example, whose interviews reveal both to hold a liberated, queer and resolutely modern model of empowered female sexuality and whose preferred body modifications - genital piercings and sado-masochistic cutting - have no direct analogue in tribal societies?

This overly broad conceptualization of the motivations of Modern Primitives' interviewees also appears in Eubanks' article Zones of Dither. Whilst she rightly claims that 'the motivation for Modern Primitives' modification of the body varies widely from subject to subject', she goes on to assert that 'a common impetus is a fascination with non-European ritualistic practices' (Eubanks 1996: 76), a statement that does not apply to Gallina, to Satanist Anton LaVey, to sideshow performers Tattoo Mike and Captain Don, or to
1.

2.

3.

4.

5.

6.

7.

8.

9.

10.

11.

12.

13.

14.

15.

16.

17.

18.

19.

20.

21.

22.

23.

24.

25.

26.

27.

28.

29.

30.

31.

32.

33.

34.

35.

36.

37.

38.

39.

40.

41.

42.

43.

44.

45.

46.

47.

48.

49.

50.

51.

52. 
several of the tattoo artists and collectors featured. Often, even in interviews where non-European practices are referred to, it is only as part of a broader modification narrative that does not fit within the paradigm of atavistic essentialist romanticism Eubanks criticizes and Musafar's philosophy normatively requires: Bill Salmon, who gets a traditional Samoan tattoo as only one amongst the vast number of others he has acquired, falls into this category, as does Jane Handel, who claims 'I wanted work that was inspired by traditional tribal designs, but contemporary too, and abstract in the sense that it wasn't rigidly symbolic of any religious or cultural references' (Jane Handel in Vale and Juno 1989: 77).

\section{MODERN PRIMITIVES AS MOVEMENT}

The second mistake made repeatedly in academic and popular readings of Modern Primitives and body modification subcultures in the 1990s is that the book either describes or went on to inspire a large and identifiable 'movement' under that name (Atkinson 2003; Atkinson and Young 2001; Campbell 1998; Cummings 2001; DeMello 1995; Pitts 2003; Rosenblatt 1997; Sweetman 1999; Torgovnick 1995; Wojcik 1995).

In some cases, this second error is intertwined with the implicit assumption of the first: that any and all body modifications should inherently be thought to be 'primitive'. From Kleese's initial error that everyone chronicled in Modern Primitives either self-identifies with this label or can be defined in the terms Musafar demarcates for modern primitivism in the book's first chapter, he allows the assumption of an underlying primitivist philosophy to leak into his more general discussions of the role of body modification in Western culture. 'Although Modern Primitives rigorously reject the materialism of Western consumer culture', he scoffs on the basis of a reading supported only by citations from Musafar and other critics such as Marianna Torgovnick who make the same error (Torgovnick 1995), 'small-scale businesses of professional piercers and tattoo artists have been established in all larger cities' (Klesse 2000: 21). This is a fallacious argument: it is certainly not the case that all or even many tattoo shop owners would subscribe the primitivism Kleese is (correctly) critiquing in his article (see for example Sanders 2008). From the simple categorical error formulated in a hasty reading of Modern Primitives, Kleese has proceeded to ascribe to a vast number of individuals an identity, a politics and even a metaphysics which they themselves would likely make no claim to.

\section{ART AND TATTOOING IN THE WEST}

The drive to call 'Modern Primitivism' a movement is further undermined by the fact that the separation of the aesthetic of traditional tribal tattooing from the ritualism that accompanies it in its original contexts was already well established in the West some years before Modern Primitives was published. Spider Webb released Pushing Ink: The Fine Art of Tattooing in 1979 and Don Ed Hardy released Tattootime: New Tribalism in 1982 (subsequently reprinted in 1988), both focussing on the aesthetic and formal qualities of tattooing as an art form rather than its spiritual or ethical potential. Alongside presentations of tattoos from the American naval tradition and tattoos in a fine art context, both works also feature images of tattooing from New Zealand, Borneo and Samoa, but with none of the ethical commentary which categorizes Musafar's contributions to Modern Primitives. The cover of New Tribalism (Figure 2) 


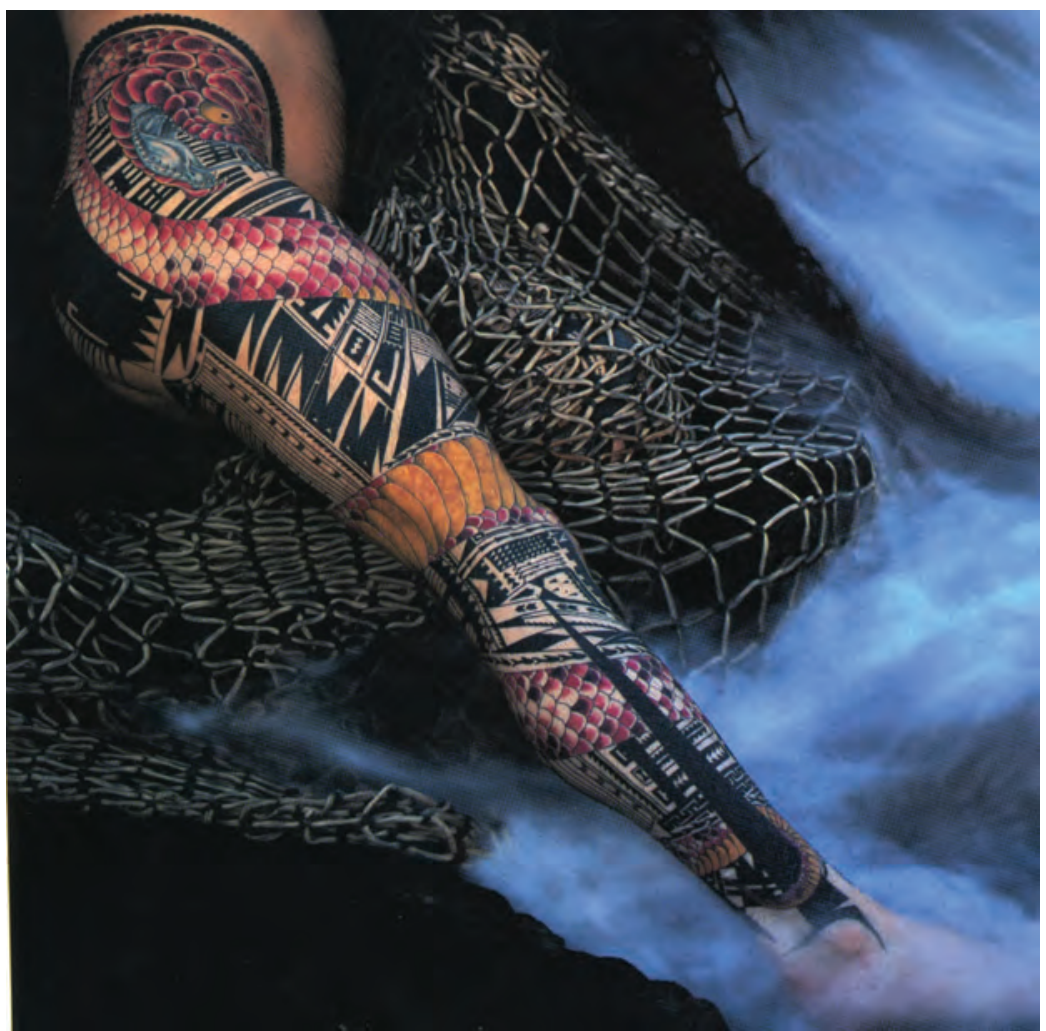

Figure 2: The Beginning of All Things. Don Ed Hardy, 1982. Photograph by Trina Von Roesenvinge.

features a photograph of a man's leg, covered in heavy blackwork in a 'tribal' style, intersected with a large, brightly coloured purple snake. This tattoo, is certainly not 'authentically' tribal in any sense, but something innovative and exciting, drawing upon the aesthetics of heavy blackwork tattooing in tribal contexts in order to create something resolutely new.

In Cliff Raven's contribution to New Tribalism, his interest in tattooing as a decorative art and in the 'treasure trove of form' becomes apparent as he waxes at length about the visual qualities of geometric black tattoos (Raven 1988). For Hardy himself, 'neo-tribal' tattooing 'does provide a powerful option for the repertoire of contemporary creative tattooing' (Hardy 1988). The fascination is in the beauty of the abstract tattoos, which accentuate and ameliorate the body they adorn, not in a particular philosophical narrative they are assumed to represent or even facilitate.

These tattoo artists and their contemporaries were already incorporating 'tribal' elements before the term 'Modern Primitives' had any currency at all, a point further underlined by Arnold Rubin's edited collection Marks of Civilisation (Rubin 1988). Marks was published in 1988 - the year before Modern Primitives. In the book's final section, a number of essays present the same moment in time as Modern Primitives, chronicle some of the practices and make mention of several of the same people who appear or are mentioned in Modern Primitives, yet their analyses of tattooing in the 1980s run entirely
1. 2. 3. 4. 5. 6. 7. 8. 9. 10. 11. 12. 13. 14. 15. 16. 17. 18. 19. 20. 21. 22. 23. 24. 25. 26. 27. 28. 
1. contrary to the broad-brushed critiques found in those that have used Modern Primitives as their primary and principal source. As Rubin explains in his introduction to this final set of papers, 'contemporary Euro-America body-art represents a distinctive and highly idiosyncratic synthesis, where the past is demonstrably prologue' (Rubin 1988: 207). Rubin identifies in the 'renaissance' of tattooing that was already emerging by 1988 a fundamental move away from primitivism and atavism towards a 'new, broad-based investigation of the expressive possibilities embodied in tattoo'. He even identifies the incorporation of 'tribal' styles as part of this emergence of an innovative 'avant-garde' in American tattooing from the 1950s onwards (Rubin 1988: 236) - an understanding of contemporary tattooing almost entirely inverse to those who have read the spread of blackwork tattoo styles as indicative of a retrograde, primitive move.

The result of all these misreadings and unsupported extrapolations is that other interesting philosophies threaded through Modern Primitives have more or less been entirely overlooked. Amongst the collection of quotations that make up the book's final section, Vale and Juno cite one of Oscar Wilde's famous aphorisms: 'One must be a work of art, or wear a work of art'. This quotation encapsulates and epitomizes the most important and most useful of these unexamined strands: the model of the body itself as a work of art. With its imperative verb, Wilde's quote is rousing, inspiring and perhaps even political. It immediately conjures up images of flamboyant dandies, resplendent in vivid outfits. It suggests that the body itself be turned into a masterpiece for others to gaze upon, ponder and enjoy. Moreover, it draws upon every Romantic trope of what an artist is and should be, encouraging creativity, dynamism, inspiration and novelty. To see the body as a work of art seems resolutely opposed to Musafar's retrospective philosophies of primitivism, which actively resist novelty and reject creativity.

\section{MODERN PRIMITIVES AND BODY ART}

Don Ed Hardy grew up in Southern California in the 1950s, and developed an interest in tattooing in his childhood, intrigued and inspired by the tattooed sailors he had seen in his neighbourhood (Govenar 2009). Whilst he was studying fine art at the San Francisco Art Institute, he describes how he 'realized that tattoo was the great undocumented folk art' (Hardy in Vale and Juno 1989: 64), a realization that propelled him to become both a tattoo artist and a keen historian and ethnographer of tattooing. In their salutary introduction to his interview, Vale and Juno hail Hardy as 'one of the foremost practitioners of the ancient art of tattoo ... a philosopher, historian, painter and innovator' (Vale and Juno 1989: 50), and, over the course of the discussion, it becomes clear that there is a vast conceptual gulf between his philosophy and the primitivism that precedes it in the book's schema. 'His goal', the editors declare, is 'to raise artistic standards and extend the range and complexity of symbolism depicted, while reinvestigating and preserving traditions' (Vale and Juno 1989: 50).

The first thing that is striking about Hardy's presentation of his work and his attitudes to his profession in the Modern Primitives interview is just how focused he is on the tattoo and the tattooed body as objects, rather than on the subjectivity of the embodied self which so preoccupies Musafar. 'Tattoo is in fact a medium', he explains - a medium he describes as often more rewarding, but equally often more frustrating than that of paint, a medium 


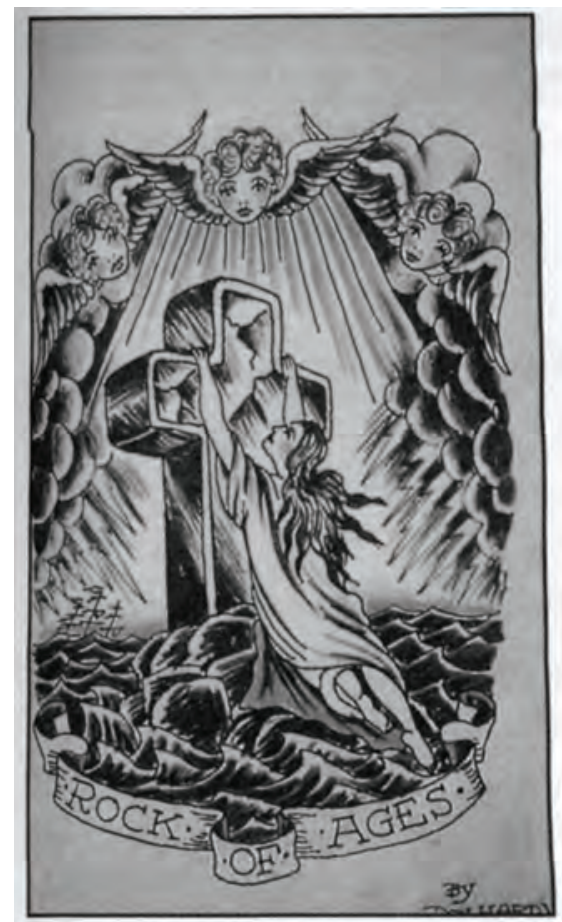

1.

Figure 3: Rock of Ages flash drawing by Don Ed Hardy, 1988. Reproduced in

bounded in any respects by the limits of the (embodied) material it requires, but a medium nonetheless. Whilst Hardy does (and is prompted to) discuss the motivational and emotional drives of his clients, the roles tattoos play in their lives and their narrative conceptions of selfhood, and whilst he considers these drives important and exciting, when given space by his interrogators to speak at length about tattooing, he always returns to questions of form, aesthetics and artistic influences. Compared with Musafar's interview, which dwells on the purity and universality of the drive to interact with one's own body, the pain of body modification and the liberatory potential of the processes he espouses, the conversation with Hardy is lighter on meditations on the process than it is on straightforward excitement about and reverence for tattoos. In one remarkable section, Vale pushes Hardy on his metaphysical perspective, stating leadingly 'It's like the tattoo opens a door to another dimension' (Vale and Juno 1989: 56). Hardy briefly agrees, though he then turns this question into an opportunity to describe how he is something of a connoisseur of tattooing, able to discern from the iconography of old sailor tattoos the date they were applied and the artist who applied them.

In a book which has so often been read as a compendium of individuals who explicitly reject the Western and Judeo-Christian culture, Hardy's interview also stands out for containing two photographs featuring an iconic Christian image, the Rock of Ages that entered the contemporary tattoo lexicon from the designs favoured by early to mid-twentieth century American servicemen (Vale and Juno 1989: 67, see Figure 3). Though Hardy's interest in the design is not predicated on its Christian allusions - he also ascribes layers of pagan symbolism to the 
image - the inclusion of these images completely undermines any homogeneous reading of the book or the culture it has been purported to represent. Hardy is as reverent about traditional Western tattooing as he is about that from Polynesia or Japan, and it is difficult to understand why this resolutely non-primitive influence on a key contributor has been overlooked by every critic who has written about Modern Primitives. The book has so often been read as an rejection of Western values, and yet it features Hardy talking at length about not only Christian symbols but also tattoos obtained during military service and his thoughts on the evocative nature of the images that had become part of the American tattoo vernacular.

The interview is liberally interspersed with literate references to art history one would expect from an arts graduate. Hardy rapidly intermeshes discussions of tattooing with references to Surrealism, Impressionism, abstract expressionism, Minimalism, the art market, Kandinsky, Cubism, the role of institutions and even Kenneth Baker - a far cry from the ninetieth-century anthropology that informs Musafar's modern primitivism. In fact, in what reads like an express rejection of Modern Primitivist ideals, he even explicitly dismisses those who would directly appropriate traditional non-Western tattooing: 'I mean, it's all right if some people really want to ape the Japanese, or whatever, but the most exciting possibility for me as an artist is to do this fusion' (Vale and Juno 1989: 54). Though he is both aware and respectful of the history of tattooing in tribal cultures, unlike Musafar he professes no desire to mimic or simply reproduce them for their own sake. Unlike in the normative expression of Modern Primitivism, which sanctions only specific types and configurations of
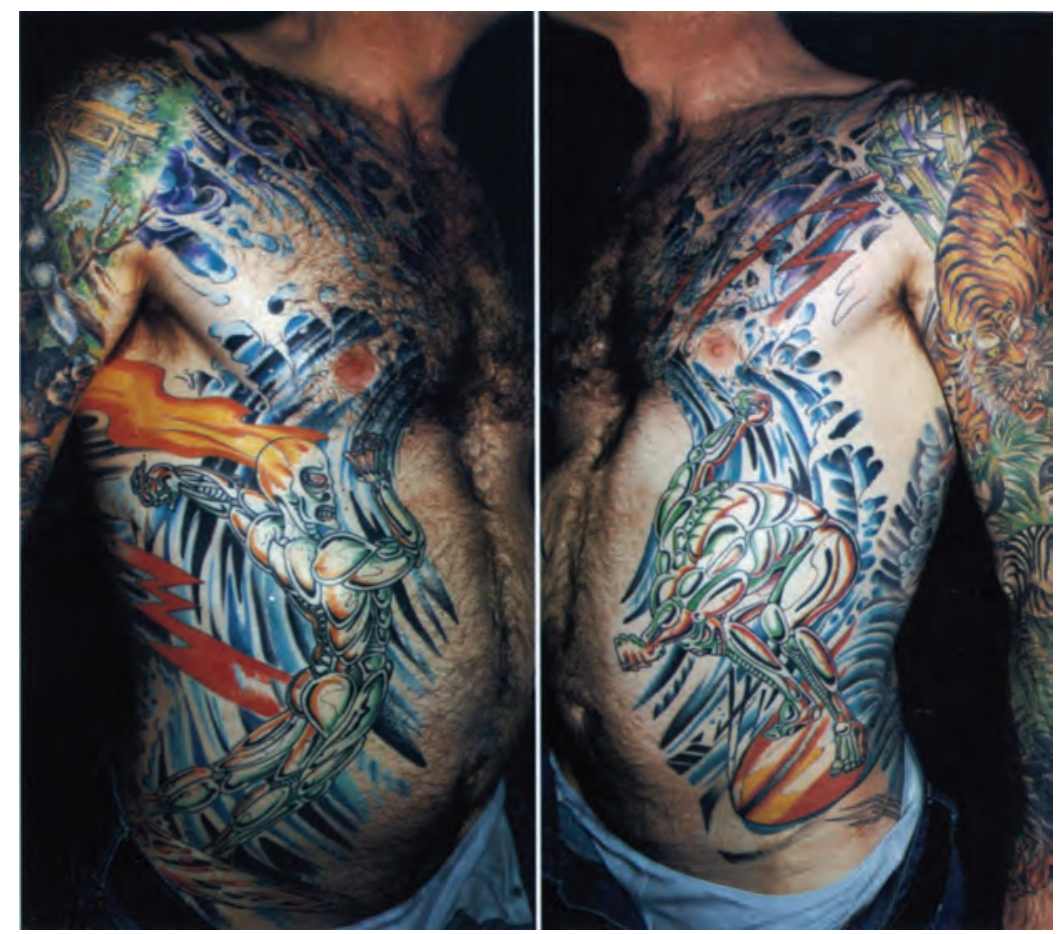

Figure 4: DNA: Tattoo to commemorate successful operation curing total paralysis from auto-accident, Don Ed Hardy, 1989. 


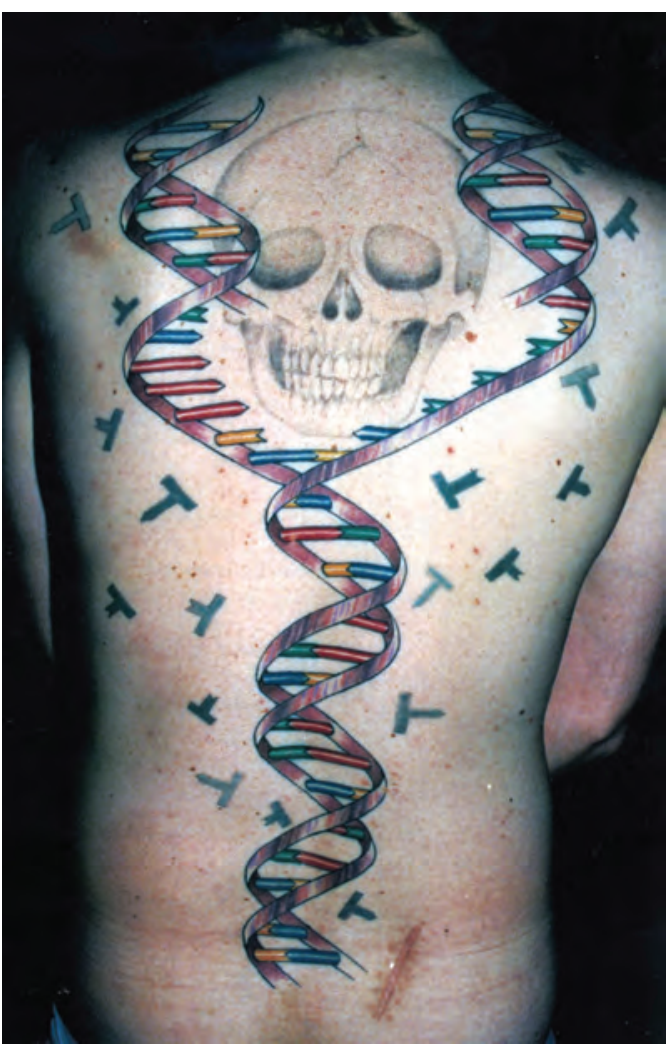

Figure 5: Robot Surfers: "Kemp Aaberg arch" (left), "Mickey Munoz Quasimoto" (right), Don Ed Hardy, 1988-90.

modifications, Hardy's model allows the 'primitive' practice to become simply a means of creating something with currency and immediacy. In this conception, tattooing is no more philosophically 'primitive' than early forms of painting or sculpture are, even if the label might be chronologically apposite.

To further illustrate and emphasize the distance in Hardy's practice from the primitivist discourse in which he has found himself subsumed, images of tattoos Hardy produced in 1989 are included as Figures 4 and 5: one being a backpiece entitled 'DNA: Tattoo to commemorate successful operation curing total paralysis from auto-accident' (as reproduced in Hardy 1991: 6), and the other a pair of rib-panels entitled 'Robot surfers: "Kemp Aaberg arch"' (left), and 'Mickey Munoz Quasimoto' (right) (Hardy 1991: 84). These pieces are testaments to some of the particularly forward-looking work Hardy was producing at the time of his interview with Vale and Juno; both pieces are imbued with science and science fiction iconography and cannot in any sense be considered primitive, atavistic or appropriational.

\section{CONCLUSIONS}

Understanding the body as an art object is not without its problems or its complexities. Nevertheless, it has been sufficient here simply to acknowledge that such a model exists, and exists at the core of a text that has usually been
1.

2.

3.

4.

5.

6.

7.

8.

9.

10.

11.

12.

13.

14.

15.

16.

17.

18.

19.

20.

21.

22.

23.

24.

25.

26.

27.

28.

29.

30.

31.

32.

33.

34.

35.

36.

37.

38.

39.

40.

41.

42.

43.

44.

45.

46.

47.

48.

49.

50.

51.

52. 
1. read as a testament to the hollow atavism of contemporary Western body modification. Modern Primitives is undoubtedly the most widely influential work on body modification practices in the West yet written - it cannot unreasonably be said to have been the impetus for the first wave of a nascent body piercing industry, which rippled across North America and Europe in the early 1990s, bringing exotic body modifications to the attention of countless people, many of whom were inspired to copy them. And yet its status as a univocal philosophical or ideological text remains unclear, despite scholarly assertion to the contrary. There never has been a 'movement' of Modern Primitives, driven by explicitly and avowedly 'primitive' desires to seek a higher state of consciousness though direct manipulation of their own flesh. Musafar's philosophy is too prescriptive and too esoteric for that ever to have been the case.

What does emerge from a different reading of Modern Primitives is that at the same time and the same place as Musafar was developing his notions of primitivism, another set of individuals, exemplified by Don Ed Hardy, were asserting a rather different model of body modification. A decade after Modern Primitives was published, Margo DeMello interviewed Hardy for her book Bodies of Inscription: 'Ed Hardy', she says, 'is both critical of modern primitivism and how he influenced it':

It's intriguing to see it [primitivist rhetoric] used by people as essentially the new kitsch. They're not very original designs, but they pick up on this thing how it's meaningful for them, how it's a journey or a rite of passage and all that stuff, and it's kind of incredible that that's going on. ... I get so sick of hearing all that stuff, and of course I know that I started a lot of it because I started focusing on that in the first TattooTime just kind of to make people aware of it, but it's just so corny now.

(Don Ed Hardy interviewed in DeMello 2000: 182)

Hardy's attitude here illustrates precisely that he has unwittingly been co-opted by cultural critics and some tattoo collectors into a discourse of primitivism which he wants to have nothing to do with. Hardy is clear: his interest is and always has been primarily in the aesthetic dimension of his craft more so than any specific notions of selfhood. What is important, rather, is the art of tattoo, the art of body art.

\section{REFERENCES}

Atkinson, M. (2003), Tattooed: The Sociogenesis of Body Art, Toronto, ON, and London: University of Toronto Press.

Atkinson, M. and Young, K. (2001), 'Flesh journeys: Neo primitives and the contemporary rediscovery of radical body modification', Deviant Behavior, 22: 2, pp. 117-46.

Campbell, A. (1998), Western Primitivism: African Ethnicity, London: Cassell.

Cummings, W. (2001), 'Modern primitivism: The recent history of civilization's discontents', in B. Herzogenrath (ed.), Critical Studies: From Virgin Land to Disney World - Nature and Its Discontents in the USA of Yesterday and Today, Amsterdam: Rodopi, pp. 297-316.

DeMello, M. (1995), “"Not just for bikers anymore”: Popular representations of American tattooing', Journal of Popular Culture, 29: 3, pp. 37-52. (2000), Bodies of Inscription: A Cultural History of the Modern Tattoo Community, Durham, NC: Duke University Press. 
Eubanks, V. (1996), 'Zones of Dither: Writing the Postmodern Body', Body $\mathcal{E}$ Society, 2: 3, pp. 73-88.

Favazza, A. R. (1996), Bodies under Siege: Self-Mutilation and Body Modification in Culture and Psychiatry, 2nd ed., Baltimore, MD, and London, Johns Hopkins University.

Fenske, M. (2007), Tattoos in American Visual Culture, New York: Palgrave Macmillan.

Govenar, A. (2009), Ed Hardy: Art for Life, Kempen, Germany: teNeues.

Hardy, D. E. (1988), TattooTime: New Tribalism, Honolulu, HI: Hardy Marks.

- (1991), TattooTime: Art from The Heart, Honolulu, HI: Hardy Marks.

Institute for Cultural Research (2000), Modern Primitives: The Recurrent Ritual of Adornment (Monograph 37), London: Institute for Cultural Research.

Klesse, C. (2000), "“Modern primitivism”: Non-mainstream body modification and racialized representation', in M. Featherstone (ed.), Body Modification, London: Sage, pp. 15-38.

MacCormack, P. (2006), 'Great ephemeral tattooed skin', Body E Society, 12: 2, pp. 57-82.

Musafar, F. (1996), 'Body play: State of grace or sickness', in A. R. Favazza (ed.), Bodies under Siege: Self-Mutilation and Body Modification in Culture and Psychiatry, Baltimore, MD, and London: Johns Hopkins University, pp. 325-34.

- (2002), Spirit + Flesh, Santa Fe, NM: Arena Additions.

_ (2003), 'Body play: State of grace or perversion', in B. A. Perlingieri (ed.), A Brief History of the Evolution of Body Adornment in Western Culture: Ancient Origins and Today, Portland, OR: Tribalife, pp. 21-44.

Perlingieri, B. A. (2003), A Brief History of the Evolution of Body Adornment in Western Culture: Ancient Origins and Today, Portland, OR: Tribalife.

Pitts, V. (2003), In the Flesh: The Cultural Politics of Body Modification, New York and Basingstoke, UK: Palgrave Macmillan.

Raven, C. (1988), 'Thoughts on pre-technological tattooing', in D. E. Hardy (ed.), TattooTime: New Tribalism, Honolulu, HI: Hardy Marks, pp. 10-11.

Rosenblatt, D. (1997), 'The antisocial skin: Structure, resistance, and "modern primitive" adornment in the United States', Cultural Anthropology, 12: 3, pp. 287-334.

Rubin, A. (1988), Marks of Civilization: Artistic Transformations of the Human Body, Los Angeles, CA: University of California Press.

Sanders, C. R. (2008), Customizing the Body - The Art and Culture of Tattooing, Philadelphia, PA: Temple University Press.

Siorat, C. (2005), 'Beyond Modern Primitivism', in N. Thomas, A. Cole and B. Douglas (eds), Tattoo - Bodies, Art and Exchange in the Pacific and the West, London: Reaktion, pp. 205-22.

Sullivan, N. (2001), Tattooed Bodies - Subjectivity, Textuality, Ethics and Pleasure, Westport, CT: Praeger.

Sweetman, P. (1999), 'Marking the body: Identity and identification in contemporary body modification', Unpublished Ph.D. thesis, University of Southampton, Southampton.

Torgovnick, M. (1995), 'Piercings', in R. D. L. Campa, E. A. Kaplan and M. Sprinkler (eds), Late Imperial Culture, London: Verso, pp. 197-210.

Turner, B. (2000), 'Body marks in cool societies', in M. Featherstone (ed.), Body Modification, London: Sage, pp. 39-50.

Vale, V. and Juno, A. (eds) (1989), Modern Primitives: An Investigation of Contemporary Adornment and Ritual, San Francisco, CA: RE/Search Publications.

1.

2.

3.

4.

5.

6.

7.

8.

9.

10.

11.

12.

13.

14.

15.

16.

17.

18.

19.

20.

21.

22.

23.

24.

25.

26.

27.

28.

29.

30.

31.

32.

33.

34.

35.

36.

37.

38.

39.

40.

41.

42.

43.

44.

45.

46.

47.

48.

49.

50.

51.

52. 
49.

50.

51.

52.
Wojcik, D. (1995), Punk and Neo-Tribal Body Art, Jackson, MI: University Press of Mississippi.

\section{SUGGESTED CITATION}

Lodder, M. (2011), 'The myths of modern primitivism', European Journal of American Culture 30: 2, pp. 99-111, doi: 10.1386/ejac.30.2.99_1

\section{CONTRIBUTOR DETAILS}

Dr Matt Lodder completed his Ph.D. at the University of Reading in 2010, having submitted a thesis entitled 'Body Art: Body Modification as Artistic Practice'. His research is concerned with the artistic status of body art and body modification practices, including tattooing, body piercing and cosmetic surgery, applying art-theoretical and art-historical methodologies to the study of the modified body specifically as an art object rather than a site for psychological, psychiatric, anthropological or ethnographic interest.Matt is currently a visiting lecturer at the University of Reading, and works as Senior Administrator for the Association of Art Historians.

Contact: 34 Parade Mansions, Watford Way, London NW4 3JJ, UK.

E-mail: matt@mattlodder.com 